\title{
EKSISTENSI SAKSI MAHKOTA DALAM PROSES PERADILAN PIDANA DI INDONESIA BERDASARKAN ASAS NON SELF INCRIMINATION
}

\author{
Ni Kadek Driptayanti, Kejaksaan Negeri Karangasem, Bali, E-mail: \\ driptayanti0@gmail.com \\ I Ketut Mertha, Fakultas Hukum Universitas Udayana, E-mail: \\ ketut_mertha@unud.ac.id
}

doi: https://doi.org/10.24843/KS.2020.v08.i12.p10

\begin{abstract}
ABSTRAK
Tujuan penelitian ini untuk mengetahui eksistensi saksi mahkota dalam proses peradilan pidana di Indonesia berdasarkan asas non self incrimination; dan perlindungan hukum terhadap saksi mahkota. Metode menggunakan jenis penelitian hukum normatif. Hasil penelitian ini menunjukkan bahwa Eksistensi saksi mahkota dalam proses peradilan pidana di Indonesia berdasarkan asas non self incrimination sudah lazim digunakan. Kehadiran saksi mahkota baru dikatakan tidak bertentangan dengan asas non self incrimination jika dilakukan sesuai dengan apa yang diatur dalam Pasal 199 jo. Pasal 200 Rancangan KUHAP versi Januari 2009; dan (2) Perlindungan hukum terhadap saksi mahkota, seperti perlindungan terhadap saksi sebagaimana diatur dalam Undang-Undang Nomor 13 Tahun 2006 tentang Perlindungan Saksi dan Korban, namun kepada saksi mahkota diberikan juga keringanan hukuman bahkan dibebaskan dari penuntutan jika peranannya dianggap yang paling ringan.
\end{abstract}

Kata kunci: Saksi Mahkota, Asas Non Self Incrimination, Perlindungan Hukum

\begin{abstract}
The objective of this research to reveal the existence of a crown witness in the criminal justice process in Indonesia based on the principle of non self-incrimination; and legal protection of crown witnesses. The method uses a type of normative legal researc. The result of this research indicates that The existence of crown witnesses in criminal justice processes in Indonesia based on the principle of non-selfincrimination is commonly used. The presence of a new crown witness is said not to contradict the principle of non-self-incrimination if it is carried out in accordance with Article 199 jo. Article 200 of the January 2009 version of the Draft Criminal Procedure Code; and Legal protection for crown witnesses, such as protection for witnesses as regulated in Law Number 13 of 2006 concerning Protection of Witnesses and Victims, however crown witnesses are also given leniency and even exemption from prosecution if their role is considered the lightest.
\end{abstract}

Keywords: Crown Witness, The Principle of Non Self Incrimination, Legal Protection.

\section{PENDAHULUAN}

\subsection{Latar Belakang masalah}

Kejahatan apapun jenis dan bentuknya, mulai dari street crime seperti pembunuhan, perampokan, penganiayaan sampai pada apa yang disebut sebagai white collar crime atau yang dikenal dengan istilah kejahatan kerah putih seperti korupsi dan sebagainya, selalu menimbulkan reaksi yang keras dari masyarakat masyarakat 
menentangnya. Arti kejahatan dipandang dari sudut formil (menurut hukum) adalah suatu perbuatan yang oleh negara diberi pidana. ${ }^{1}$

Salah satu upaya menanggulangi kejahatan adalah melalui hukum pidana². Penanggulangan kejahatan dengan hukum pidana pada hakikatnya juga merupakan bagian dari usaha penegakan hukum (khususnya penegakan hukum pidana). ${ }^{3}$ Walaupun penegakan hukum pidana dalam rangka penanggulangan kejahatan bukan merupakan satu-satunya tumpuan harapan, ${ }^{4}$ namun keberhasilan nya sangat diharapkan karena pada bidang penegakan hukum inilah dipertaruhkan makna dari "negara berdasarkan atas hukum". 5

Penegak hukum seringkali menghadapi halangan tambahan dalam menyelidiki dan menuntut kasus besar yang sensitif. Selain itu, kejahatan besar yang kerap terjadi ini seringkali nampak diatur secara vertikal, dengan partisipasi dari para pejabat di tingkat yang lebih tinggi yang mempunyai posisi cukup kuat untuk membujuk pejabat yang berada di tingkat yang lebih rendah agar tidak bekerjasama, atau sebaliknya untuk menghalangi penyidikan.

Indriyanto Seno Adji dalam makalahnya menyebutkan mengenai pentingnya saksi yang juga pelaku kejahatan yang merupakan "orang dalam" (inner-cicle criminal) karena dianggap mempunyai potensi dalam membuka tabir kejahatan. Kadangkala "orang dalam" ini adalah pelaku yang terlibat dalam kejahatan. Ia dapat menyediakan bukti yang penting mengenai siapa yang terlibat, apa peran masing-masing pelaku, bagaimana kejahatan itu dilakukan, dan dimana bukti lainnya bias ditemukan. Selain dari memberikan petunjuk bagi para penyidik, orang dalam ini kadangkala berpartisipasi dalam penyidikan. Akhimya, orang dalam ini dapat menjadi saksi yang sangat penting sewaktu persidangan, memberi bukti sebagai orang pertama, saksi mata dari kejahatan atas kegiatan para terdakwa. ${ }^{6}$

Saksi yang juga seorang pelaku dalam perkara yang sama dalam praktik disebut dengan saksi mahkota. Sering kita mendengar berita mengenai saksi mahkota di berbagai media cetak dan elektronik. Berita mana di antaranya menyebutkan bahwa saksi mahkota adalah saksi yang juga berkedudukan sebagai tersangka. Kemampuan seorang saksi untuk memberikan kesaksiannya dalam proses peradilan atau untuk bekerja sama dengan penegak hukum penting sekali dalam mengungkap atau membuka tabir kejahatan. ${ }^{7}$

1 W.A. Bonger.. Pengantar Tentang Kriminologi, (terj. R.A. Koesnoen). Jakarta: PT.Pembangunan, (1995), h.21.

2 Barda Nawawi Arief. Kebijakan Hukum Pidana. Bandung: Citra Aditya Bhakti, (1996). h.48.

${ }^{3}$ Barda Nawawi Arief. Bunga Rampai Kebijakan Hukum Pidana PerkembanganPenyusunan Konsep KUHP Baru. Jakarta: Kencana Prenada Media Group, (2008). h. 24

${ }^{4}$ Muladi. Kapita Selekta Sistem Peradilan Pidana. Semarang: Badan Penerbit Undip, (1995). h.viii.

5Ibid, h.7

${ }^{6}$ Indriyanto Seno Adji. Prospek Perlindungan Saksi dan Korban Dalam Sistem Hukum Pidana Indonesia, Indonesia Law Review, Vol.III, No.2, (2007). h.21.

7 Dwinanto Agung Wibowo. Peranan Saksi Mahkota dalam Peradilan Pidana di Indonesia. Jurnal Hukum dan Pembangunan, Vol.III, No.1, (2011). h.63 
Keberadaan saksi mahkota walaupun dikenal dalam praktik peradilan pidana di Indonesia, tidak terlepas dari pihak-pihak yang pro dan kontra terhadap penerapannya. Indriyanto Seno Adji dalam makalahnya mengemukakan beberapa alasan dari pihak yang kontra terhadap penerapan saksi mahkota dalam proses peradilan pidana. ${ }^{8}$ Alasan pertama, pengajuan saksi mahkota bertentangan dengan hak asasi manusia, khususnya berkaitan dengan hak-hak terdakwa dalam proses peradilan pidana, yaitu melanggar "non self incrimination" yang secara universal mendapat pengakuan dunia. Implisitas pengakuan adanya "non self incrimination" disebutkan melalui Pasal 189 ayat (3) Undang-Undang Nomor 8 Tahun 1981 tentang Kitab Undang-Undang Hukum Acara Pidana (KUHAP), yang berbunyi "Keterangan terdakwa hanya dapat dipergunakan terhadap dirinya sendiri". Hal ini berarti bahwa terdakwa mempunyai hak untuk tidak mempersalahkan dirinya sendiri sejak proses penyidikan sampai dengan proses persidangannya di pengadilan. Jelaslah, apabila kedudukan seorang terdakwa dalam suatu berkas perkara pidana tertentu ditarik sebagai saksi dalam berkas perkara pidana lainnya yang terpisah namun mengenai tindak pidana yang sama adalah melanggar hak asasi manusia, khususnya hak terdakwa mengenai "non self incrimination". Tidak mungkinlah bagi seorang terdakwa akan mempersalahkan dirinya sendiri dengan memberikan kesaksian yang memberatkan dirinya sendiri dalam berkas perkara pidana yang dibuat secara terpisah, misalnya: dalam suatu berkas, terdakwa menyangkal perbuatannya, namun dalam kedudukannya sebagai saksi dalam berkas pidana yang terpisah ia mengakui melakukan perbuatan yang disangkalnya sendiri. Alasan kedua, berkaitan dengan bunyi salah satu pasal dalam KUHAP mengenai pihak-pihak yang dapat mengundurkan diri sebagai saksi yaitu dalam Pasal 168 KUHAP, yang berbunyi:

Kecuali ketentuan dalam hukum undang-undang ini, maka tidak dapat didengar keterangannya dan dapat mengundurkan diri sebagai saksi:

1. Keluarga dan anak atau saudara dalam garis lurus ke atas atau ke bawah sampai derajat ketiga dari terdakwa atau yang bersama-sama sebagai terdakwa;

2. Saudara dari terdakwa atau yang bersama-sama sebagai terdakwa, saudara ibu atau saudara bapak, juga mereka yang mempunyai hubungan karena perkawinan dan anak-anak saudara terdakwa sampai derajat ketiga;

3. Suami atau istri terdakwa meskipun sudah bercerai atau yang bersama- sama sebagai terdakwa.

Ketentuan tersebut menunjukkan bahwa seseorang "yang bersama-sama" kedudukannya sebagai terdakwa tidak dapat memberikan kesaksian dalam perkara pidana yang sama dan dibuat secara terpisah (splitsing) berdasarkan ketentuan Pasal 142 KUHAP, dalam arti seorang terdakwa dalam satu berkas perkara pidana tertentu tidak dapat dijadikan saksi dalam perkara lainnya terhadap dakwaan melakukan tindak pidana yang sama, meskipun berkasnya dibuat secara terpisah.

Di sisi lainnya, saksi mahkota dipandang mempunyai daya potensial dalam membuka tabir kejahatan. Terlebih lagi kejahatan yang melibatkan beberapa pelaku yang telah mengembangkan ikatan yang kuat satu sama lain dan bersifat tertutup, baik melalui koneksi pribadi atau koneksi bisnis ataupun melalui perkumpulan profesi,

${ }^{8}$ Indriyanto Seno Adji. op.cit, h.17-18. 
seperti halnya tindak pidana korupsi. Ikatan seperti ini seringkali saling menguntungkan yang akan menyebabkan para pelaku tersebut untuk bersatu dalam menghadapi penyidikan atau kemungkinan adanya sebuah tuntutan untuk melindungi kepentingan mereka. Sehubungan dengan sifat dasar dari kasus-kasus organized crime atau white colar crime, maka kasus-kasus ini lebih sulit untuk dibuktikan daripada dengan kasus tindak pidana kriminal lainnya. ${ }^{9}$

Saksi merupakan orang atau pihak yang terlibat dalam hukum acara pidana. Oleh karena itu saksi mempunyai hak yang diberi perlindungan dan jaminan sebagaimana halnya dengan tersangka atau terdakwa. ${ }^{10}$ Namun pengaturan tentang saksi di dalam KUHAP yang selama ini menjadi landasan beracara di dalam peradilan pidana di Indonesia, justru tidak mengatur mengenai hak dan perlindungan terhadap saksi secara memadai. Hal ini disebabkan karena perspektif yang dipakai KUHAP lebih mementingkan perlindungan terhadap tersangka atau terdakwa dalam proses peradilan pidana. ${ }^{11}$

Baru pada tanggal 11 Agustus 2006, disahkan Undang-Undang Nomor 13 Tahun 2006 tentang Perlindungan Saksi dan Korban yang merupakan ketentuan khusus tentang Perlindungan terhadap saksi dan korban. Undang-Undang Nomor 13 Tahun 2006 mengatur mengenai perlindungan terhadap saksi yang juga berkedudukan sebagai tersangka dalam perkara atau kasus yang sama, yaitu dalam Pasal 10 ayat (2) Undang-Undang Nomor 13 Tahun 2006 yang lengkapnya berbunyi: "Seorang saksi yang juga tersangka dalam kasus yang sama tidak dapat dibebaskan dari tuntutan pidana apabila ia ternyata terbukti secara sah dan meyakinkan bersalah, tetapi kesaksiannya dapat dijadikan pertimbangan hakim dalam meringankan pidana yang akan dijatuhkan". Dari frasa "dapat" dalam ketentuan tersebut menunjukkan bahwa perlindungan berupa pemberian keringanan pidana bersifat fakultatif, yang secara implisit belum menunjukkan adanya perhatian terhadap saksi yang telah berperan membantu dalam mengungkap kejahatan. Dibutuhkannya ketentuan perlindungan terhadap saksi bukan sekadar memberikan kepastian hukum tetapi juga menjamin perlindungan terhadap saksi yang juga berkedudukan sebagai tersangka atau terdakwa yang membantu dalam mengungkap kejahatan dengan memberikannya penghargaan atas kesaksiannya tersebut.

\subsection{Rumusan Masalah}

Berdasarkan uraian di atas maka rumusan masalah dalam penelitian ini sebagai berikut: pertama, bagaimana eksistensi saksi mahkota dalam proses peradilan pidana di Indonesia berdasarkan asas non selfincrimination?; dan Kedua, bagaimana perlindungan hukum terhadap saksi mahkota?

${ }_{9}^{9}$ Putusan Mahkamah Konstitusi No. 42/PUU-VIII/2010 tanggal 3 September 2010.

10 Suryono Sutarto. Hukum Acara Pidana Jilid 1. Semarang: Badan Penerbit Undip, (1991). h.12.

11 Setiyono. Eksistensi Saksi Mahkota sebagai Alat Bukti dalam Perkara Pidana. Lex Jurnalica, Vol5, No.1, (2007). h.20. 


\subsection{Tujuan Penelitian}

Tujuan penelitian ini untuk menganalisis: pertama, eksistensi saksi mahkota dalam proses peradilan pidana di Indonesia berdasarkan asas non self incrimination; dan kedua, perlindungan hukum terhadap saksi mahkota.

\section{Metode Penelitian}

Metode penelitian yang digunakan dalam penelitian ini adalah jenis penelitian hukum normatif. Penelitian hukum normatif (normative legal research) merupakan penelitian yang dilakukan dengan cara mengkaji peraturan perundang-undangan yang berlaku atau diterapkan terhadap suatu permasalahan hukum tertentu. Penelitian hukum normatif meneliti hukum dari perspektif internal dengan objek penelitiannya adalah norma hukum. ${ }^{12}$ Penelitian normatif seringkali disebut dengan penelitian doktrinal, yaitu penelitian yang objek kajiannya adalah dokumen peraturan perundang-undangan dan bahan pustaka. ${ }^{13}$ Penelitian hukum normatif juga disebut penelitian yang difokuskan untuk mengkaji penerapan kaidah-kaidah atau norma dalam hukum positif. ${ }^{14}$ Menurut I Made Pasek Diantha penelitian hukum normatif berfungsi untuk memberi argumentasi yuridis ketika terjadi kekosongan, kekaburan dan konflik norma. Lebih jauh ini berarti penelitian hukum normatif berperan untuk mempertahankan aspek kritis dari keilmuan hukumnya sebagai ilmu normatif. ${ }^{15}$

\section{HASIL DAN PEMBAHASAN}

\subsection{Eksistensi Saksi Mahkota dalam Proses Peradilan Pidana di Indonesia Berdasarkan Asas Non Self Incrimination}

Untuk menyatakan salah atau tidaknya seorang terdakwa, tidak cukup berdasarkan keyakinan hakim semata-mata. Atau hanya semata-mata didasarkan atas keterbuktian menurut ketentuan dan cara pembuktian dengan alat-alat bukti yang ditentukan undang-undang. Seorang terdakwa baru dapat dinyatakan bersalah apabila kesalahan yang didakwakan kepadanya dapat dibuktikan dengan cara dan dengan alat-alat bukti yang sah menurut undang-undang serta sekaligus keterbuktian kesalahan itu "dibarengi" dengan keyakinan hakim. Bertitik tolak dari uraian diatas, untuk menentukan salah atau tidaknya seorang terdakwa menurut sistem pembuktian undang-undang secara negatif, terdapat dua komponen :

1. Pembuktian harus dilakukan menurut cara dan dengan alat-alat bukti yah sah menurut undang-undang.

2. Dan keyakinan hakim yang juga harus didasarkan atas cara dan dengan alat-alat bukti yang sah menurut undang-undang.

12 I Made Pasek Diantha. Metodologi Penelitian Hukum Normatif dalam Justifikasi Teori Hukum. Jakarta: Prenada Media Group, (2017). h.12.

${ }^{13}$ Peter Mahmud Marzuki. Penelitian Hukum. Jakarta: Kencana Prenida Media, (2011). h.34.

${ }^{14}$ Johny Ibrahim. Teori dan Metodologi Penelitian Hukum Normatif. Malang: Banyumedia, (2012). h.295.

${ }^{15}$ I Made Pasek Diantha, op.cit. h.12. 
Dengan demikian, sistem ini memadukan unsur "objektif" dan "subjektif" dalam menentukan salah atau tidaknya terdakwa. Tidak ada yang paling dominan diantara kedua unsur tersebut. Jika salah satu diantara dua unsur itu tidak ada, tidak cukup mendukung keterbuktian kesalahan terdakwa. Misalnya, ditinjau dari segi cara dan dengan alat-alat bukti yang sah menurut undang-undang, kesalahan terdakwa cukup terbukti, tetapi sekalipun sudah cukup terbukti, hakim "tidak yakin" akan kesalahan terdakwa, dalam hal seperti ini terdakwa tidak dinyatakan bersalah.

Jika dilihat kembali apa yang menjadi tujuan hukum, yaitu untuk menciptakan tatanan masyarakat yang tertib dan menciptakan keseimbangan. Sudah menjadi kewajiban semua pihak untuk menghormati setiap hak dan kewajiban yang dimiliki oleh masyarakat. KUHAP sebagai karya agung anak Bangsa memiliki tujuan yaitu salah satunya adalah melindungi hak asasi para tersangka/terdakwa. Jika dihubungkan berdasarkan Teori Keadilan Aristoteles, pemaksaan terhadap seorang tersangka/ terdakwa untuk mengakui kesalahannya jelas bertentangan dengan semangat dan cita-cita hukum yaitu untuk menciptakan suatu keadilan. Karena suatu keadilan ditandai oleh hubungan yang baik antara satu dengan yang lain, tidak mengutamakan diri sendiri, tapi juga tidak mengutamakan pihak lain, yang terpenting adalah adanya kesamaan. Kesamaan disini melahirkan sebuah prinsip, yakni semua orang sederajat di depan hukum dan prinsip memberi tiap orang apa yang menjadi haknya ${ }^{16}$.

Asas hukum praduga tak bersalah, sejak abad ke 11 dikenal di dalam sistem hukum Common Law, khususnya di Inggris, dalam Bill of Rights (1648). Asas hukum ini dilatarbelakangi oleh pemikiran individualistic-liberalistik yang berkembang sejak pertengahan abad ke 19 sampai saat ini. Di dalam sistem peradilan pidana (criminal justice system) berdasarkan sistem hukum Common Law (system adversarial/sistem kontest), asas hukum ini merupakan prasyarat utama untuk menetapkan bahwa suatu proses telah berlangsung jujur, adil, dan tidak memihak (due process of law). Asas praduga tak bersalah merupakan bagian yg tidak terpisahkan dari prinsip due process tersebut. Friedman menegaskan bahwa, prinsip "due process" yang telah melembaga dalam proses peradilan sejak dua ratus tahun yang lampau, kini telah melembaga di dalam seluruh bidang kehidupan sosial. ${ }^{17}$ Konsekuensi logis dari asas praduga tak bersalah ini maka kepada tersangka atau terdakwa diberikan hak oleh hukum untuk tidak memberikan keterangan yang akan memberatkan atau merugikan dirinya di muka persidangan (the right of non-self incrimination), dan untuk tidak memberikan jawaban baik dalam proses penyidikan maupun dalam proses persidangan (the right to remain silent). ${ }^{18}$

Untuk mewujudkan due process of law (proses hukum yang adil) dalam pelaksanaan peradilan pidana sudah selayaknya menjamin hak asasi manusia. Tobias

16 Bernard L Tanya, Yoan N Simanjuntak, dan Markus Y Hage. Teori Hukum Strategi Tertib Manusian Lintas Ruang dan Generasi. Yogyakarta: Genta Publishing, (2013). h. 42.

${ }^{17}$ Lawrence M Friedman. The Legal System: A Sicial Perespecive. New York: Russe Sage Foundatino, (2005). h. 63

18 Irfan Maulana Muharikin. Kedudukan Saksi Mahkota dalam Proses Peradilan Pidana di Indonesia Berdasarkan Asas Non Self Incrimination. Jurnal Arena Hukum, Vol.V, No.3, (2015). h.35-36. 
dan Petersen dalam Mardjono Reksodiputro, ${ }^{19}$ mengatakan unsur minimal dari proses hukum yang adil itu adalah "hearing, councel, defence, evidence and a fair and impartial court" (mendengar tersangka dan terdakwa, penasihat hukum, pembelaan, pembuktian dan pengadilan yang adil dan tidak memihak). Pengertian proses peradilan yang adil lebih dari sekedar penerapan hukum formil melainkan terkandung penghargaan atas hak seorang warga negara. ${ }^{20}$ Dengan memberikan penghargaan terhadap saksi yang juga pelaku kejahatan yang telah membantu mengungkap perkara pidana dan bekerjasama dengan penegak hukum merupakan cerminan hak perlindungan terhadap saksi. ${ }^{21}$

Asas non self incrimination memang tidak diatur secara tegas dalam KUHAP. Dengan tidak diaturnya asas ini dalam KUHAP tidak berarti bahwa Indonesia tidak mengakui asas non self incrimination dalam proses peradilan pidana. Indonesia meratifikasi International Covenant on Civil and Political Rights (ICCPR) melalui Undangundang No.12 Tahun 2005. Sebagai salah satu negara anggota yang meratifikasi ICCPR maka Indonesia memiliki kewajiban untuk mematuhi kaidah-kaidah yang dimuat dalam konvensi internasional tersebut. Salah satunya adalah mengenai asas non self incrimination.

Asas non self incrimination yang dimasukkan sebagai salah satu indikator fair trial memberikan konsekuensi yaitu pengajuan saksi mahkota merupakan hal yang sangat bertentangan dengan prinsip-prinsip peradilan yang baik dan tidak memihak (fair trial) dan juga termasuk pelanggaran terhadap kaidah hak asasi manusia. Sistem peradilan pidana dalam KUHAP mengutamakan perlindungan hak asasi manusia, yang merupakan suatu sistem agar masyarakat dapat menghayati hak dan kewajibannya. Dalam KUHAP sendiri pun secara tersirat sebenarnya telah memuat mengenai asas non self incrimination. Hal ini tercermin secara parsial melalui Pasal 66 KUHAP bahwa tidak ada beban kewajiban pembuktian bagi terdakwa (beban pembuktian menjadi kewajiban penuntut umum), Pasal 175 KUHAP yang menyiratkan adanya hak ingkar bagi terdakwa, Pasal 189 ayat (3) KUHAP bahwa keterangan terdakwa hanya dapat dipergunakan bagi dirinya sendiri, dan tidak adanya pengakuan terdakwa sebagai alat bukti yang sah sebagaimana diatur dalam Pasal 184 ayat (1) KUHAP, serta Pasal 168 KUHAP tentang pengecualian yang bersifat relatif untuk menjadi saksi.

Berdasarkan Pasal 189 ayat (3) KUHAP dijelaskan bahwa keterangan terdakwa hanya berlaku bagi dirinya sendiri. Keterangan terdakwa tidak dapat digunakan untuk membuktikan kawan terdakwa yang lain. Pada praktiknya, karena pengadilan berulang-ulang berpendapat bahwa yang dinamakan kawan terdakwa itu hanyalah bila beberapa orang terdakwa dituntut bersama-sama di dalam satu pengadilan.

19 Ibid. h. 27.

${ }^{20}$ Mardjono Reksodiputro. Hak Asasi Manusia Dalam Sistem Peradilan Pidana, Kumpulan Karangan Buku Ketiga. Jakarta: Pusat Pelayanan Keadilan dan Pengabdian Hukum Universitas Indonesia, (2007). h.28

${ }^{21}$ Made Dharma Weda. Hak Atas Keadilan. Depok: Sentra HAM Universitas Indonesia, (2013). h.12-45. 
Adapun dengan pemecahan suatu perkara menjadi beberapa perkara maka para terdakwanya tidak dituntut dalam satu sidang lagi. ${ }^{22}$

Pendapat seperti ini cenderung kurang tepat mengingat yang dinamakan kawan terdakwa dalam tindak pidana penyertaan adalah mereka yang melakukan, menyuruh melakukan, turut serta melakukan, dan mereka yang dengan memberi atau menjanjikan sesuatu, dengan menyalahgunakan kekuasaan atau martabat, dengan kekerasan, ancaman atau penyesatan, atau dengan memberikan kesempatan, sarana, atau keterangan, sengaja menganjurkan orang lain supaya melakukan tindak pidana (Pasal 55 ayat (1) KUHAP). Tidak peduli apakah perkaranya dipisah atau tidak, mereka tetap dianggap sebagai pelaku tindak pidana penyertaan dan satu sama lain disebut sebagai kawan terdakwa.

Terdakwa pada dasarnya memiliki hak untuk diam dan hak untuk tidak menjawab atau menolak pertanyaan yang diajukan kepadanya. Hak ini ada kaitannya dengan kebebasan tersangka atau terdakwa untuk memberikan keterangan secara bebas kepada penyidik atau hakim yang merujuk pada Pasal 52 KUHAP. Berdasarkan penjelasan pasal ini dikatakan bahwa agar pemeriksaan dapat mencapai hasil yang tidak menyimpang daripada yang sebenarnya maka tersangka atau terdakwa harus dijauhkan dari rasa takut oleh karena itu wajib dicegah adanya paksaan ataupun tekanan terhadap tersangka atau terdakwa. ${ }^{23}$

Terdakwa pertama yang diajukan sebagai saksi mahkota dalam perkara pidana di mana tamannya yang merupakan peserta pada tindak pidana penyertaan tersebut duduk sebagai terdakwa, diharuskan memberikan kesaksian di bawah sumpah yang mengikat dirinya. Dia diperiksa sebagai saksi sehingga ia terpaksa memberikan keterangan yang dapat memberatkan dirinya sendiri apabila ia diperiksa sebagai terdakwa nantinya. Jika keterangan yang diberikan di dalam kedudukannya sebagai terdakwa bertentangan dengan keterangan yang diberikan dalam kedudukannya sebagai saksi dalam perkara pidana terdakwa lainnya, dia dapat diancam dengan pidana sumpah palsu. ${ }^{24}$

Seperti yang telah dikemukakan di atas bahwa ketika saksi mahkota memberikan kesaksiannya di persidangan, ia dalam kondisi di bawah sumpah. Konsekuensi dari adanya pelanggaran terhadap sumpah tersebut adalah terdakwa akan dikenakan atau diancam dengan dakwaan baru berupa tindak pidana kesaksian palsu sebagaimana yang diatur dalam Pasal 242 Kitab Undang-Undang Hukum Pidana (selanjutnya disebut KUHP).

Terdakwa akan mendapatkan tekanan psikologis akibat dari sumpah yang diucapkan saat memberikan kesaksian sebagai saksi mahkota. Ia tidak lagi mempunyai hak ingkar sebagaimana ketika ia berada dalam posisi sebagai terdakwa. Keterangan

22 R. Soesilo. Teknik Berita Acara (Proses Verbal), Ilmu Bukti, dan Laporan. Bogor: Politeia, (2010). h.8.

${ }^{23}$ M. Yahya Harahap. Pembahasan Permasalahan dan Penerapan KUHAP: Pemeriksaan Sidang Pengadilan, Banding, Kasasi dan Peninjauan Kembali. Jakarta: Sinar Grafika, (2008). h.351.

${ }^{24}$ Eko Condro Saputro. Kedudukan Saksi Mahkota (Kroongetuige) dalam Pembuktian Tindak Pidana Pembunuhan di Persidangan. Jurnal Jurisprudence, Vol.II, No.1, (2015). h.44. 
yang ia berikan dalam kapasitasnya sebagai saksi sangat mungkin digunakan oleh penuntut umum untuk menjeratnya dalam sidang di mana ia duduk sebagai terdakwa.

Kebijakan yang mendukung penggunaan kesepakatan kerja sama ini adalah bahwa kepentingan umumlah yang mengurangi hukuman dari pelaku yang tidak dominan dalam suatu kegiatan kriminal, jika kerja sama dari pelaku yang bersangkutan itu dapat membuktikan dan menghukum aktor-aktor kriminal lainnya yang lebih penting. Terdakwa yang bekerja sama haruslah juga mengakui tindak pidananya sendiri dan mendapatkan hukuman, akan tetapi prospek pengurangan hukuman melalui kesepakatan kerja sama ini merupakan dorongan yang kuat bagi si terdakwa untuk menjadi 'alat bukti bagi negara' (saksi mahkota). ${ }^{25}$

\subsection{Perlindungan Hukum terhadap Saksi Mahkota}

Saksi mahkota adalah saksi yang juga sebagai pelaku kriminal yang membongkar kejahatan. Polemik terjadi manakala ada upaya memperkenalkan kolaborasi antara pelaku kriminalitas dan penegak hokum yang dikenal sebagai saksi mahkota. Perlindungan kepada seseorang yang pada saat bersamaan adalah saksi dan juga sebagai terdakwa namun bekerjasama dengan penegak hukum adalah memberi kekebalan dari penuntutan dan pengurangan hukuman tetapi harus sesuai dengan asas hukum nasional tiap Negara peserta.

Pelaku kejahatan saat ini sudah sedemikian rapi dan terorganisir dalam melakukan perbuatannya, bahkan akibat perkembangan kejahatan itu, kita mengenal istilah white collar crime (kejahatan kerah putih), kejahatan korporasi dan kejahatan secara terorganisir (berjamaah). Pelaku kejahatan itu dapat berasal dari individu yang memiliki intelektual dan memiliki strata sosial yang tinggi di masyarakat, pejabat publik, badan hukum bahkan mafia yang paling ditakuti dan dihormati di masyarakat.

Jenis kejahatan sebagaimana disebut di atas, yakni terorganisir dan modus operandi yang cukup canggih tentunya hanya diketahui oleh orang dalam untuk mengungkapkan fakta perbuatan pidana dimaksud di persidangan atau kepada publik ketika proses hukum terjadi, mengungkap dan membuktikan terjadinya tindak pidana korupsi tidaklah mudah karena kecerdikan dan kelihaian pelaku dalam memutarbalikkan fakta sebenarnya atau menghilangkan dokumen (surat-surat) sebagai barang bukti.

Perubahan taktik dalam strategi memenangkan perang terhadap korupsi ini antara lain, memberikan perlindungan hukum terhadap pelaku suap (penerima atau pemberi) yang pertama melaporkan kepada penegak hukum tentang terjadinya penyuapan dengan tujuan yang lebih besar yaitu mengungkapkan jaringan korupsi yang sudah sistematik dan meluas. Pemberian perlindungan hukum ini sudah tentu harus selektif dan penuh kehati-hatian sehingga hanya orang yang tepat termasuk yang sudah teruji baik, yang berhak menerimanya.

Tindak pidana korupsi biasanya terungkap setelah berlangsung dalam tenggang waktu yang lama dan pada umumnya melibatkan sekelompok orang yang saling menikmati keuntungan dari tindak pidana itu. Kekhawatiran akan keterlibatannya

25 Lilik Mulyadi. Putusan Hakim Dalam Hukum Acara Pidana: Teori, Praktik, Teknik Penyusunan dan Permasalahannya. Bandung: Citra Aditya Bakti, (2007). h. 29. 
sebagai tersangka maka diantara sekelompok orang tersebut akan saling menutupi. Demikian juga dengan rasa solidaritas kelompok, kebanggaan korps yang menimbulkan rasa malu bila kelompok atau institusinya dilanda korupsi, membuat mereka anggota kelompok sekalipun tidak terlibat, senantiasa akan berupaya menutupi atau membela temannya yang dituduh korupsi. ${ }^{26}$

Konsep pendekatan yang telah diterapkan dalam Undang-Undang Nomor 13 Tahun 2006 tentang Perlindungan Saksi dan Korban (Undang-Undang No. 13 Tahun 2006) hendaknya dapat diikuti dalam upaya pemberantasan tindak pidana dengan modus operandi yang dilakukan secara sistematis dan terorganisir lainnya, misalnya: tindak pidana terorisme, perdagangan orang, pencucian uang dan lain-lain.

Penerapan konsep protection of cooperating person sebagaimana terdapat dalam Pasal 10 ayat (2) Undang-Undang No. 13 Tahun 2006 merupakan kebijakan hukum pidana (penal policy) yang sudah sangat tepat mengingat untuk pembuktian suatu tindak pidana yang dilakukan dengan modus operandi yang sistematis dan terorganisir. Tugas yang dirasakan berat oleh penuntut umum atau polisi jikalau dalam suatu tindak pidana sangat sulit untuk mengumpulkan alat bukti berupa saksi yang melihat sendiri, mendengar sendiri atau mengalami sendiri suatu tindak pidana dimana para pelaku melakukan perbuatannya dengan rapi dan terorganisir.

Penerapan konsep protection of cooperating person hendaknya sungguh-sungguh memperhatikan dan mempertimbangkan kriteria atau acuan dalam hal apakah dan bagaimana konsep ini diberlakukan. Namun demikian, masih terdapat banyak perbedaan pendapat dikalangan para praktisi dan akademisi yang menilai bahwa perlindungan terhadap saksi mahkota yang secara eksplisit diatur dalam Pasal 10 ayat (1) Undang-Undang No. 13 Tahun 2006 menyebutkan bahwa "Seorang saksi, korban dan pelapor tidak dapat dituntut secara hukum baik pidana maupun perdata atas laporan kesaksian yang akan, sedang, atau telah diberikan". Aturan yang termuat dalam Pasal 10 ayat (1) Undang-Undang No. 13 Tahun 2006 ini menjadi ambigu dan bersifat kontradiktif terhadap pasal yang sama dalam ayat (2), yakni: "Seorang saksi yang juga tersangka dalam kasus yang sama tidak dapat dibebaskan dari tuntutan pidana apabila ia ternyata terbukti secara sah dan meyakinkan bersalah, tetapi kesaksiannya dapat dijadikan pertimbangan hakim dalam meringankan pidana yang akan dijatuhkan".

Isi Pasal 10 ayat (2) Undang-Undang No. 13 Tahun 2006, terdapat kata-kata "saksi yang juga tersangka" merupakan rumusan yang kurang bisa dipahami secara konsisten terhadap saksi yang juga berstatus sebagai saksi pelapor kemudian tiba-tiba berubah menjadi tersangka. Hal ini dapat menimbulkan multitafsir dan menimbulkan ketidakpastian hukum.

Pasal 10 ayat (2) Undang-Undang No. 13 Tahun 2006 membuat pemahaman terhadap saksi yang juga tersangka semakin tidak jelas, karena di sana dijelaskan bahwa seorang saksi yang juga tersangka tidak dapat dibebaskan dari tuntutan hukum baik pidana maupun perdata. Hal ini berarti bisa saja pada waktu bersamaan seorang saksi menjadi tersangka, meskipun menurut Pasal 10 ayat (2) Undang-Undang No. 13

26 Septian Tri Yuwono. Kajian Kedudukan dan Nilai Pembuktian Saksi Mahkota sebagai Alat Bukti dalam Pembuktian Tindak Pidana Korupsi. Jurnal Privat Law, Vol.III, No.3, (2011). h.53. 
Tahun 2006 ini, memungkinkan akan memberikan keringanan hukuman bagi saksi mahkota, namun kemungkinan tersebut tetap tidak dapat membuat seorang yang menjadi saksi mahkotakan bernafas lega atau bahkan sama sekali tidak membuat seseorang tertarik untuk menjadi saksi mahkota.

Seorang yang telah menjadi saksi mahkota, apabila mengacu pada Pasal 10 ayat (2) Undang-Undang No. 13 Tahun 2006, harapan untuk lepas dari tuntutan hukum sangat sulit, karena pasal ini telah menegaskan bahwa seorang saksi yang juga tersangka dalam kasus yang sama tidak dapat dibebaskan dari tuntutan pidana apabila ia terbukti secara sah dan meyakinkan bersalah. Padahal untuk bisa lepas dari tuntutan hukum adalah menjadi harapan bagi saksi mahkota yang sekaligus juga sebagai pelaku tindak pidana, karena untuk dapat bebas dari tuntutan hukum, hampir tidak mungkin. Selain ketentuan Pasal 10 ayat (2) Undang-Undang No. 13 Tahun 2006, Pasal 191 ayat (1) KUHAP menentukan bahwa jika pengadilan berpendapat bahwa dari hasil pemeriksaan di sidang pengadilan, kesalahan terdakwa atas perbuatan yang didakwakan kepadanya tidak terbukti secara sah dan meyakinkan, maka terdakwa diputus bebas.

Sementara itu, saksi mahkota yang juga sebagai pelaku tindak pidana diduga kuat telah melakukan kesalahan, dan karenanya sangat mudah untuk membuktikannya di pengadilan. Yang memungkinkan baginya adalah lepas dari tuntutan hokum sebagaimana terdapat dalam Pasal 191 ayat (2) KUHAP yang menyebutkan bahwa jika pengadilan berpendapat bahwa perbuatan yang didakwakan kepadanya terbukti, tetapi perbuatan itu tidak merupakan suatu tindak pidana, maka terdakwa diputus lepas dari segala tuntutan hukum.

Hanya saja untuk lepas dari tuntutan hukum juga sulit, karena saksi mahkota yang juga sebagai pelaku tindak pidana yang diduga kuat telah melakukan kesalahan, tindakannya tidak termasuk dalam kerangka dasar penghapusan pidana. Meskipun saat ini telah ada Lembaga Perlindungan Saksi dan Korban (LPSK) yang menjalankan tugas memberi perlindungan bagi saksi dan korban. Namun LPSK sayangnya belum menjangkau saksi mahkota, Undang-Undang No. 13 Tahun 2006 tidak mencantumkan bahwa saksi mahkota adalah pihak yang diberikan perlindungan. Hanya saksi dan korban yang diatur dalam undang-undang tersebut. Untuk itu rumusan Pasal 33 UNCAC seharusnya dimasukkan dalam Undang-Undang No. 13 Tahun 2006.

Perihal saksi pelaku yang bekerjasama atau saksi mahkota diatur lebih lanjut oleh Surat Edaran Mahkamah Agung (SEMA) Nomor 4 Tahun 2011 tentang Perlakuan bagi Pelapor Tindak Pidana (Whistleblower) dan Saksi Pelaku yang Bekerjasama (Justice Collaborators) di dalam Perkara Tindak Pidana Tertentu (SEMA No. 4 Tahun 2011) yang dikeluarkan pada tanggal 10 Agustus 2011. Pada Pasal 10 Undang-Undang No. 13 Tahun 2006:

(1) Saksi, Korban, dan pelapor tidak dapat dituntut secara hukum baik pidana maupun perdata atas laporan, kesaksian yang akan, sedang, atau telah diberikannya.

(2) Seorang Saksi yang juga tersangka dalam kasus yang sama tidak dapat dibebaskan dari tuntutan pidana apabila ia ternyata terbukti secara sah dan meyakinkan bersalah, tetapi kesaksiannya dapat dijadikan pertimbangan hakim dalam meringankan pidana yang akan dijatuhkan. 
Pasal 10 Undang-Undang No. 13 Tahun 2006 telah berupaya mengatur tentang saksi pelaku yang bekerjasama atau saksi mahkota, namun kemudian lahir SEMA No. 4 Tahun 2011 sebagai pedoman penerapannya.

Pasal 10 Undang-Undang No. 13 Tahun 2006 menimbulkan permasalahan penafsiran ketika ada seorang saksi yang juga merupakan tersangka pada kasus yang sama. Kedua ayat pada pasal tersebut menimbulkan pertentangan satu sama lain ketika dipertemukan pada seorang saksi yang juga merupakan tersangka pada kasus yang sama. Pada ayat pertama dikatakan bahwa saksi yang melaporkan dan bersaksi tidak dapat dipidana, namun pada ayat kedua dikatakan bahwa jika saksi adalah tersangka pada kasus yang sama maka tidak dapat dibebaskan dari tuntutan pidana. Sementara, mandat Lembaga Perlindungan Saksi dan Korban hanya melindungi saksi dan korban, bukan tersangka, sehingga masalah pada Pasal 10 ini kemudian menimbulkan ambiguitas mengenai status perlindungan oleh Lembaga Perlindungan Saksi dan Korban pada yang bersangkutan.

Sebelum adanya SEMA No. 4 Tahun 2011, tampak bahwa Pasal ini tidak dapat membedakan antara pelapor dengan saksi mahkota, sehingga pengadilan juga tidak dapat memberikan perlakuan yang tepat. Menurut SEMA No. 4 Tahun 2011, pedoman untuk menentukan seseorang sebagai 'saksi pelaku yang bekerjasama' adalah bahwa yang bersangkutan merupakan salah satu pelaku tindak pidana tertentu sebagaimana dimaksud dalam SEMA No. 4 Tahun 2011. Selanjutnya SEMA No. 4 Tahun 2011 mengharuskan bahwa yang bersangkutan mengakui kejahatan yang dilakukannya, bukan pelaku utama dalam kejahatan tersebut serta memberikan keterangan sebagai saksi di dalam proses peradilan.

Ketentuan ini menimbulkan pemahaman bahwa pengakuan akan menjadi bagian penting dari sistem peradilan pidana di Indonesia. Selama ini, kedudukan pengakuan pelaku dalam sistem hukum pidana di Indonesia tidak menempati posisi yang signifikan dalam mencari kebenaran materiil. Namun, SEMA No. 4 Tahun 2011 justru menempatkan pengakuan sebagai pedoman untuk menentukan seseorang sebagai saksi pelaku yang bekerjasama yang dapat menjadi kunci bagi upaya pengungkapan kasus-kasus.

Tindak pidana tertentu yang ditentukan oleh SEMA No. 4 Tahun 2011 adalah tindak pidana korupsi, terorisme, tindak pidana narkotika, tindak pidana pencucian uang, perdagangan orang, maupun tindak pidana lainnya yang bersifat terorganisir, telah menimbulkan masalah dan ancaman yang serius terhadap stabilitas dan keamanan masyarakat sehingga meruntuhkan lembaga serta nilai-nilai demokrasi, etika dan keadilan serta membahayakan pembangunan berkelanjutan dan supremasi hukum.

Selanjutnya, SEMA No. 4 Tahun 2011 juga mengatur bahwa untuk menentukan seseorang sebagai saksi pelaku yang bekerjasama adalah bahwa Penuntut Umum di dalam tuntutannya menyatakan bahwa yang bersangkutan telah memberikan keterangan dan bukti-bukti yang signifikan sehingga penyidik dan/atau Penuntut Umum dapat mengungkap tindak pidana secara efektif, mengungkap pelaku-pelaku lainnya yang memiliki peran lebih besar dan/atau mengembalikan asset-aset/hasil suatu tindak pidana. 


\section{KESIMPULAN}

Eksistensi saksi mahkota dalam proses peradilan pidana di Indonesia berdasarkan asas non self incrimination sudah lazim digunakan. Kehadiran saksi mahkota baru dikatakan tidak bertentangan dengan asas non self incrimination jika dilakukan sesuai dengan apa yang diatur dalam Pasal 199 jo. Pasal 200 Rancangan KUHAP versi Januari 2009.

Perlindungan hukum terhadap saksi mahkota, seperti perlindungan terhadap saksi sebagaimana diatur dalam Undang-Undang Nomor 13 Tahun 2006 tentang Perlindungan Saksi dan Korban, namun kepada saksi mahkota diberikan juga keringanan hukuman bahkan dibebaskan dari penuntutan jika peranannya dianggap yang paling ringan.

\section{DAFTAR PUSTAKA}

\section{Buku}

Arief, Barda Nawawi. Kebijakan Hukum Pidana. Bandung: Citra Aditya Bhakti. (1996). . Bunga Rampai Kebijakan Hukum Pidana PerkembanganPenyusunan Konsep KUHP Baru. Jakarta: Kencana Prenada Media Group. (2008).

Bonger, W.A. Pengantar Tentang Kriminologi, (terj. R.A. Koesnoen). Jakarta: PT.Pembangunan. (1995).

Diantha, I Made Pasek. Metodologi Penelitian Hukum Normatif dalam Justifikasi Teori Hukum. Jakarta: Prenada Media Group. (2017).

Friedman, Lawrence M. The Legal System: A Sicial Perespecive. New York: Russe Sage Foundatino. (2005).

Harahap, M. Yahya. Pembahasan Permasalahan dan Penerapan KUHAP: Pemeriksaan Sidang Pengadilan, Banding, Kasasi dan Peninjauan Kembali. Jakarta: Sinar Grafika. (2008).

Ibrahim, Johny. Teori dan Metodologi Penelitian Hukum Normatif. Malang: Banyumedia. (2012).

Marzuki, Peter Mahmud. Penelitian Hukum. Jakarta: Kencana Prenida Media. (2011).

Muladi. Kapita Selekta Sistem Peradilan Pidana. Semarang: Badan Penerbit Undip. (1995).

Mulyadi, Lilik. Putusan Hakim Dalam Hukum Acara Pidana: Teori, Praktik, Teknik Penyusunan dan Permasalahannya. Bandung: Citra Aditya Bakti. (2007).

Reksodiputro, Mardjono. Hak Asasi Manusia Dalam Sistem Peradilan Pidana, Kumpulan Karangan Buku Ketiga. Jakarta: Pusat Pelayanan Keadilan dan Pengabdian Hukum Universitas Indonesia. (2007).

Soesilo, R. Teknik Berita Acara (Proses Verbal), Ilmu Bukti, dan Laporan. Bogor: Politeia. (2010).

Sutarto, Suryono. Hukum Acara Pidana Jilid 1. Semarang: Badan Penerbit Undip. (1991).

Tanya, Bernard L., Yoan N Simanjuntak, dan Markus Y Hage. Teori Hukum Strategi Tertib Manusian Lintas Ruang dan Generasi. Yogyakarta: Genta Publishing. (2013).

Weda, Made Dharma. Hak Atas Keadilan. Depok: Sentra HAM Universitas Indonesia. (2013).

\section{Jurnal}

Adji, Indriyanto Seno. Prospek Perlindungan Saksi dan Korban Dalam Sistem Hukum Pidana Indonesia, Indonesia Law Review, Vol.III, No.2. (2007). 
Muharikin, Irfan Maulana. Kedudukan Saksi Mahkota dalam Proses Peradilan Pidana di Indonesia Berdasarkan Asas Non Self Incrimination. Jurnal Arena Hukum, Vol.V, No.3. (2015).

Saputro, Eko Condro. Kedudukan Saksi Mahkota (Kroongetuige) dalam Pembuktian Tindak Pidana Pembunuhan di Persidangan. Jurnal Jurisprudence, Vol.II, No.1. (2015).

Setiyono. Eksistensi Saksi Mahkota sebagai Alat Bukti dalam Perkara Pidana. Lex Jurnalica, Vol5, No.1. (2007).

Wibowo, Dwinanto Agung. Peranan Saksi Mahkota dalam Peradilan Pidana di Indonesia. Jurnal Hukum dan Pembangunan, Vol.III, No.1. (2011).

Yuwono, Septian Tri. Kajian Kedudukan dan Nilai Pembuktian Saksi Mahkota sebagai Alat Bukti dalam Pembuktian Tindak Pidana Korupsi. Jurnal Privat Law, Vol.III, No.3. (2011).

\section{Peraturan Perundang-Undangan}

Kitab Undang-Undang Hukum Pidana.

Undang-Undang Nomor 8 Tahun 1981 tentang Kitab Undang-Undang Hukum Acara Pidana.

Undang-Undang Nomor 13 Tahun 2006 tentang Perlindungan Saksi dan Korban. Putusan Mahkamah Konstitusi No. 42/PUU-VIII/ 2010 tanggal 3 September 2010.

Surat Edaran Mahkamah Agung (SEMA) Nomor 4 Tahun 2011 tentang Perlakuan bagi Pelapor Tindak Pidana (Whistleblower) dan Saksi Pelaku yang Bekerjasama (Justice Collaborators) di dalam Perkara Tindak Pidana Tertentu. 